\title{
Perspectives on the Notion of Truth in Arabic Philosophy
}

\author{
Hamdi Mlika \\ University of Kairouan \\ Rakada 3100, Kairouan, Tunisia \\ e-mail:mlika_hamdi@yahoo.fr
}

\begin{abstract}
:
In the present paper, I assume that the notion of "truth" in philosophy would not have been clarified and tackled properly, if philosophers did not take into account earlier Arabic Medieval research contributions and build upon previous research findings. In the first place, I embark on the scrutiny of the rich aspect (or nature) of the Arabic Lexicon in terms of the "truth" meaning. In the second place, I take on the assumption that Arabic linguistic traditions imply different kinds of truths, depending on various spheres of human thoughts and actions based on the logical approach to "truth" (from Al-Kindi up to Averroes via Al-Farabi and Avicenna) and the term "al-haqiqha" as transliterated from Arabic, remain central. In conclusion, I take on an approach to "truth" that gives worth to logical perspectives at the very heart of Medieval Arab traditions in the light of what I would label as the "Omni-cultural Universality of Logic and Science".

Keywords: Truth, Arabic philosophy, haqiqha, Omni-cultural universality, AlKindi, Al-Farabi, Avicenna, Averroes.
\end{abstract}

\section{Introduction}

Do the notions of "Truth" and "Reality" exist in particular cultures while they might not be present in others? It is this question, which belongs to the anthropology of knowledge, that Paul Jorion puts under scrutiny in a book entitled "Comment la vérité et la realité sont inventées?" [16, p. 7]. In the four-chapter book, Jorion attempts to demonstrate that both truth and reality have "actually appeared at specific moments in the history of Western culture and are totally absent from the conceptual baggage of some others ...". The term "Truth" dates back to the Fourth Century BC Greece, and "reality" (objective) to $16^{\text {th }}$ Century Europe. One term stems from the other: Since then, the idea of "Truth" imposes itself, to speak the truth is to describe reality as it is [16, p. 7]. Although the author utters a value judgment that can relegate such cultures as China, he does not focus on the case of the Arab culture.

The questions that arise in favor of Paul Jorion's thoughts are as follows: (1) The notion of "Truth" (and its correlating ideas: that of objective reality) being invented in specific historical processes, something that no one dares to dispute - would they be absent from the conceptual schema of Arab language and culture? (2) Are they, on the contrary, present but in a form which is 
different from what we find in Western culture, and displaying other features? In any case, the answer to the last two questions presupposes the answer to three other questions which I formulate as follows:

(3) What is the relation of Arab culture and language to the Greek way of thinking with regard to the notion of truth?

(4) Is Arab philosophy the pale image of Greek thought without manifesting the least linguistic specificity or conceptual originality?

(5) And if the notion of truth was found by a happy combination of circumstances represented in Arab thought and language, would it be one or multiple?

These are precisely the questions that I would like to raise in the present paper, which will deal with the very key principle of the Multi-cultural universality of truth, thus opposing the Western thesis that sees in the 'Greek miracle' the solution to the question of "Truth".

\section{Approaches to the Notion of Truth}

I would like to highlight that the notion of "Truth" in Arabic culture and language need to take into account the plurality of systems in which it unfolds and the variety of interpretations that are attached to it. I am inclined to think that the systematic approaches to truth correspond to five in terms of number:

(1) First, the system proper to the demonstrative reason rightly embodied by Averroes (d.1198) and the rationalist philosophers, heirs to Al-Kindi (d. 873) and Peripatetic Arabic philosophy in general (represented above all by the House of wisdom in Baghdad).

(2) Second, the system that stems from the illuminative, mystical and intuitive experience with its distinctive features, rightly incarnated by Sufi Mansur Al-Hallağ ${ }^{1}$ and other philosophers such as Suhrawardi, Al-Gazali, and Avicenna as well though by poets singing of the drunkenness of love such as Ibn 'Arabi.

(3) Third, the system which rather focuses on the literality of the Qur'anic text without sinking into any form of occult or fundamentalist thought, a system that the Zahirism of Ibn Hazm (d.1064), an Andalusian philosopher, expresses with elegance.

(4) Then comes the system of traditions that do not separate the truth apart from the different dialectical, rhetorical and argumentation procedures relating to speech acts; I am thinking here of Kalam $^{2}$ (rational theology) in general, especially Mu'aatzilism and Ach'aarism.

(5) In addition to all these Arabic intellectual traditions are the four different doctrines of Islamic law and jurisprudence (Fiqh, Muslim law, the reflection of jurists in relation to the Qur'an) and the system of the foundations of religion. It should be noted that the word Haqq for example and its plural Huquq are attached to Islamic law (Šariia') and human rights in the sense of positive law (Huquq al-insan).

This general outline is not exhaustive and can be further revised and examined. I am far from claiming to deepen under this schema all the ramifications of the concept of "Truth". I simply sought to "model" the different currents of thought around the theme of truth in Arabic culture, taking into account its key role in global history. Moreover, to insist on the polysemic side of the word truth in Arabic language, I would state that its meaning remains linked to its use in the various discourses and to its status in a given conceptual assemblage. My goal is therefore to put in an order that is at once rational, ethical and pragmatic, the different semantic layers related to this notion, and to see if there is not an interpretative path capable of leading us to think them all as maintaining among them a certain air of family. I therefore put out the question pertaining to the specificity of Arabic contribution, through these multiple uses and classical traditions. I mainly focus on the "Haqiqha" term, because I think it encompasses the meaning of other terms that express the truth. I first ask the following question: "What are the features implied by this notion of Haqiqha?" 


\section{Polysemy of the Term Haqiqha}

To answer this question without limiting myself to the logical sense strongly marked in my point of view, I would say that if we refer for example to Seyyed Hossain Nasr in his book entitled The Garden of Truth, we will realize that the term Haqiqha means several things at once: ${ }^{3}$

1) Truth is a supreme goal that remains to be achieved. In other words, truth is primarily conceived of as the culmination of a whole cognitive journey and is therefore defined as a horizon of thought and life.

(2) Truth is what bases our actions and justifies them as virtuous and just.

(3) Truth is grasped as being engaged in an idealized process of knowledge that must lead to what we can call deliverance, bliss or salvation.

(4) Haqiqha henceforth signifies a love of the truth. Truth remains without real value if it is not taken in a strong emotional and sentimental impulse.

(5) There comes a fifth aspect of the truth where it is held primarily for one of the expressions of divine essence: Al-Haqq is one of the names attributed to God. ${ }^{4}$

(6) Finally, we can say that the notion of Haqiqha is inseparable from a whole methodology of procedural verification that we designated by the Arabic term Tahqiqh, or spiritual self-realization that we designated by the Arabic term Tahaqquqh [19, p. 30]. This ratio is proportional to that which we establish between truth and verification. I mean that the truth is essentially inseparable from an immersion process through some essentially ethical and spiritual practices and devices.

It is not wrong to say that expressions other than Haqiqha translate the meaning of the word truth into the Arabic language and culture. Indeed, besides Haqiqha, we find a series of other expressions that each accounts in its own way for the meaning of the word truth. The question that arises from the outset is: besides the term Haqiqha, what are these words that express in Arabic the true and the truth? For my part, and given the richness of the Arabic lexicon, I can quote at least five terms: Sidq, Haqq, Șawab, Șahih and Haqiqha. I will try here to develop this polysemy in a sort of interpretation that will put them in agreement. This matching of Sidk (logically true/true from a logical point of view), Haqq (Absolute True), Sawab (the state of a well-fitting idea, an idea or opinion that aims its object), Șahih (valid in opposite to false (Fasid)) and Haqiqha (truth) is not always obvious. Note that the two terms of Haqq and Haqiqha derive from the same verbial root, namely Haqaqha, and can indicate two meanings often given for the opposite: Haqq and Haqiqha may mean the truth in the sense that it is identifiable with revelation to the Qur'an, to God himself, but also to the result of the use of human demonstrative reason. Indeed, these two terms can also mean truth in the sense that it is involved in adequate human thought with reality and physical substances. It would not be justified here to speak of two kinds of truths: one rational, while the other is religious. It is indeed the conclusion that Averroes will draw much later when he contests in his famous Decisive Treatise the double standard of the truth and will preach its inseparable unity. For him, there is no place for two truths, but rather for two processes, two different routes that lead to one truth.

Since, therefore, writes Averroes in the Decisive Treatise, this revelation is the truth, and it calls to practice the rational examination which ensures the knowledge of the truth, then we Muslims know with certainty that the examination of Being by demonstration will entail no contradiction with the teachings brought by the revealed text: for the truth cannot be contrary to the truth, but agrees with it and testifies in its favor [5, p. 119].

If we focus on the term "truth" (Haqiqha) in so far as it refers to a concept whose universality is omni-cultural ${ }^{5}$, we will find that its fate remains decisive at the very heart of Arabic culture.

Indeed, the approach of truth in this culture, with its specific anthropological colors, must help us to move towards a model which, while being particular and linked to its own history, can fit with the characteristics considered universal. One can fall into a double misunderstanding of the plural traditions that weave the central core of Arabic culture: whether they are seen as a mere extension of what has been accomplished by the Greeks, or whether they are interpreted as having 
nothing to do with an Islamic thought that essentially relates to religion. I think that the approach of the notion of truth in the context of Arabic culture and philosophy will undoubtedly make us avoid falling into such a mistake.

The word Haqiqha is a noun derived from the root of the verb Haqaqha. In his famous encyclopedic dictionary of the Arabic language, Lisân Al-'Arab, Ibn Manzur (d. 1311) gives us the multiple etymological roots of the word in question [18, Volume X, pp. 49-58]. I will therefore use this interdisciplinary lexicological approach to identify the distinctive features of this concept and emphasize its polysemy. I must note that Ibn Manzur uses in his linguistic dictionary several sources to clarify the different meanings of the terms of the Arabic language. These sources are based on oral or written Arabic traditions, the Qur'ran, prophetic narratives (Hadith and Sirha), poetry, historical narratives, quotations from eminent 'Ulama, etc. Ibn Manzur opposes the truth in language to everything that comes from a figurative use of words. The concept of truth is thus immediately defined as being closely interdependent with the traits of rightness, certainty, adequacy with the essences of things, stability in judgment, obligation, necessity, and many other traits again. The first words of Ibn Manzur pose the True (Haqq) as the opposite of the unjust and the false (Batel). In its adverbial use, truth means the insistence on the act in question which makes it more certain. The word Haqq also refers to the message of the prophet and to what he has brought more substantial, that is to say the Qur'an. It is in this context that the surahs (chapters) of the Qur'an abound in verses that incite believers not to dress truth with lies and to defeat truth with falsehood. In other words, the true obliges and imposes. The true speech is a stable, invariant, obligatory, binding, decided, sliced, inescapable and imposing act. In this sense, the true is necessary and functions both as a right (Haqq) and a duty (Wağeb): one must manifest the truth and make no concession to it. Thus, the suffering of the disbelievers in hell is true, which means that it was decided by God and proves to be in this sense inevitable. A speech is qualified as true when it imposes itself on the greatest number, and in this sense this speech is confirmed as not tolerating any doubt. The verb Haqaqqha applied to a speech or a fragment of language means to believe in its truth in the sense of the word Sidq (true in the logical sense) and to hold it as true. In this sense, to reach the truth of a thing is to obtain a certainty about it. This meaning is clear in the following saying that one attributes to the Prophet: None reaches the truth of faith (that is to say, its purity and its quintessence) if one does not stop blaming their brother for a defect which is rather in him. The truth of a person is what the person in question must protect, defend and prevent others from appropriating.

\section{Arabic Philosophies of Truth}

It is widely acknowledged that the truth among classical Arabic philosophers manifests itself as a logical concept par excellence. But it must not be clearly distinguished from any mystical posture, or from any realistic position in the physical sense. He remains present in all these areas. The logical perspective, however, remains open to the possibility of expanding through a questioning of the classical metaphysical principles that guide it. As an example, I can quote the criticism of AlSuhrawardi (d. 1191) of the notion of definition in Aristotle on strictly illuminative bases. The mystical posture of logic basically means that logic remains revisable as to its principles, and therefore is likely to take on new extensions. It is in this sense that we must understand the questioning of the law of non-contradiction in the work of Graham Priest where the Australian logician tries to valorize the true contradictory propositions to better open the logic on the Buddhist spiritual experience [20]. ${ }^{6}$

To return to the context of Arabic culture, the two striking examples in this sense are AlĠhazali (d. 1111) and Avicenna (d. 1037). For these two eminent Arabic philosophers and logicians, it is not permissible to oppose logic and illuminative access to the truth. The first will extract the logical norms (in total agreement with the logic of Aristotle) of the Qur'an itself, while the second will operate in its treatise on The Logic of the Easterners a quite exceptional turning point from a simple logical approach inductive and deductive to an illuminative system that fuses 
intuitive knowledge and deduction. It should be noted at the outset that classical Arabic logic remains inseparable from a psychological and metaphysical theory of the faculties of the soul and a semantic and semiotic theory adjusted to the Arabic language. However, this logical sense must not exclude any interaction with other meanings and uses of the truth. In addition to its logical scope, which is emphasized by philosophers, there is its position within the so-called rhetorical, dialectical, pragmatic and conversational disciplines of grammarians.

In addition to the philosophical understanding of Logic as a foundation, we see a new language approach in the heart of Arab culture, particularly represented by Abd al-Qahir AlĞurğani (d. 1078), Abu Ya'qub Al-Sakkaki (d. 1229), and many other theorists of Arabic language and literature.

Clearly, the philosophical conception is related to a theory essentially based on truth as adequacy or correspondence to the state of the world. It is indeed the true-false duality that is sometimes criticized via the role that the beliefs that accompany the assertions of truth are invited to play in the determination of the true judgment. Indeed, we find in certain Arab rhetorical traditions the intention to transgress true-false dualism to leave more room for a third option between truth and falsity. Such a trend has also emerged in the field of Islamic law and jurisprudence or Fiqh (Islamic law). This third possibility between the case of the true and the false suggests the possibility for judgments to be neither true nor false. Without doubt, the polysemy of these terms of true and truth is related to the variety of approaches, to the multiplicity of traditions and systems of knowledge and interpretation.

To return to what I said at the beginning of this chapter, the question of truth is seldom dealt with in terms of an analytical approach. There is a tendency to consider the question of truth as a metaphysical subject par excellence, often treated through a traditional philosophical methodology using a largely synthetic style. Indeed, this question has often been addressed in strictly ideological, descriptive and historical terms. Among those who have (rarely) addressed this question in the context of classical Arab intellectual traditions, and who have relied on the kind of analysis we find in the history of science ${ }^{7}$ and in analytic philosophy, we find Ali Benmakhlouf, who spoke about it in an article published in Arabic titled "Reasoning and Truth in the Medieval Arab Philosophical Tradition" $[8] .^{8}$

I will therefore deal with this question in the philosophical tradition in the Arabic language which has developed following the movement of translation of Greek philosophical works through the Persian and Syriac languages, without dealing directly and profoundly with the other traditions that make up the all of the Arab-Islamic heritage, from Fiqh to Kalam.

In its general sense, the question of truth has occupied an important place in Arab culture. Now, in spite of its expressly interdisciplinary character, I will limit myself to the philosophical style with which this question has arisen. This style was rightly incarnated in the $9^{\text {th }}$ century by AlKindi (d. 874), a style that will be reinforced by other eminent thinkers such as Al-Farabi (d. 950) in the $10^{\text {th }}$ and especially the philosopher of Cordova Averroes (d. 1198). Indeed, since Al-Kindi, considered as the father of the Arab philosophy, a first philosophical approach to the truth begins to emerge, characterized above all by its explicit references to Greek philosophical sources (and more particularly to the two great systems formed by the theses of Plato and Aristotle).

In the image of Greek philosophy, Arab philosophy has sought to draw its limits, often from within its own discourse, by confronting them with the other components of culture and society: mythological thought, theological discourse (kalamist), the religious discourse, the discourse of the economic and political power in place, etc. Many people mistakenly believe that it is possible for us to discern in traditional Arab culture a kind of pure $\log o s$, a core of intact rationality. I think this is a very difficult, if not impossible, business.

A quick review of classical Arabic philosophy ${ }^{9}$ (with logic as its inseparable core) and its particular epistemological status within the history of medieval philosophy and the history of science $^{10}$ (since the Arabs allowed Logic to detach from Aristotle and the Stoics to develop as a universal science closely related to semiotics and semantics, will lead us to the following urgent 
question: In what sense can this return to Arab Logic help us to develop, from within the cultural heritage of the Arab world, a distinctive approach to the concept of truth?

I will analyze four examples from classical Arab philosophy and see how we could use them to develop such an approach to truth. This approach is proving to be very helpful in responding to the extremist discourse that often goes against openness to others, pluralism, humanism, intercultural dialogue, and especially against a rationality that we posit from the outset as logical.

\subsection{Al-Kindi or How Did We Become the Heirs of All Who Sought the Truth}

For the father of Arabic philosophy, Al-Kindi, the first philosophy or Metaphysics stands out from other disciplines by the nobility of its subject, i.e., the knowledge of the first truth which is the cause of all other truths. Therefore, the most perfect and noble philosopher would be the man who would fully master this kind of knowledge. However, such a common treasure of humanity could not have been born without solidarity, through the long centuries of history, philosophers from many cultures and speaking different languages. No language or culture should claim to possess all the truth and therefore all this common treasure. Truth is the business in the making of the very partial and minimal contributions of every culture, language, and nation. It is in this sense that AlKindi writes in his Epistle on the first philosophy:

The truth requires that we do not reproach anyone who is even one of the causes of even small and meager benefits to us; how shall we treat those who are responsible for many causes, of large, real and serious benefits to us? Though deficient in some of the truth, they have been our kindred and associates in that they benefited us by the fruits of their thought, which have become our approaches and instruments, leading to much knowledge of that the real nature of which they fell short of obtaining. We should be grateful particularly since it has been clear to us and to the distinguished philosophers before us who are not our co-linguists, that no man by the diligence of his quest has attained the truth, i.e., that which the truth deserves, nor have the philosophers as a whole comprehended it. Rather, each of them either has not attained something any truth or has attained something small in relation to what truth deserves. When, though, the little which each one of them who has acquired the truth is collected, something of great worth is assembled from this. It is proper that our gratitude be great to those who have contributed even a little of the truth, let alone to those who have contributed much truth, since they have shared with us the fruits of their thought and facilitated for us the true (yet) hidden inquiries, in that they benefited us by those premises which facilitated our approaches to the truth. If they had not lived, these true principles with which we have been educated towards the conclusions of our hidden inquiries would not have been assembled for us, even with intense research throughout our time. But indeed this has been assembled only in preceding past ages, age after age, until this our time, accompanied by intensive research, necessary perseverance and love of toil in that. In the time of one man-even if his life span is extended, his research intensive, his speculation subtle and he is fond of perseverance - it is not possible to assemble as much as has been assembled, by similar efforts, - of intense research, subtle speculation and fondness for perseverance - over a period of time many times as long [3, p. 57].

Al-Kindi undoubtedly draws here the foundations of the universality of philosophy and science which rest above all on the omni-culturality of knowledge and its transmission. And one of the direct consequences of this posture is inevitably manifested in the strength and objectivity with which truth must be imposed on all men without concessions. It is in these terms that Al-Kindi expresses himself: 
We ought not to be ashamed of appreciating the truth and of acquiring it wherever it comes from, even if it comes from races distant and nations different from us. For the seeker of truth nothing takes precedence over the truth, and there is no disparagement of the truth, nor belittling either of him who speaks it or of him who conveys it. (The status of) no one is diminished by the truth; rather does the truth ennoble all [3, p. 58].

\subsection{Al-Farabi and the Universality of Logic}

I would like to quote a very interesting passage from The Catalogue of the Sciences (Ihsa' al 'Ulum) by Abu Nasr Al-Farabi. It is instructive to stress that for him, linguistic skills and logical ones go hand in hand, even if he does not confuse them. If the consideration of language (what the terms mean for a given linguistic community) is interesting philosophically, the logic however differs from the linguistic perspective by its aim to access a universal intelligibility: Logic is moved by a different intentionality than language. The relationship between Logic and Grammar is neither identity nor opposition: Al-Farabi associates the two in his philosophical enterprise to better dissociate them. Both are indispensable. Both of them respect their own principles and assume distinct tasks. But in principle, the Logic is superior. ${ }^{11}$

From Al-Farabi's point of view, the universality of logic takes away the universality of particular languages. The community of linguistic structures (between different languages) is only misleading. The important thing is to be aware of it and to interpret this distance between the two aspects, without apprehending it as an absolute or impassable limit. In fact, the terms of language are only the repository signs of an intelligibility that goes beyond the simple verbal form or behavior socially anchored. Here settles a positive interaction between the two. Linguistics and grammar do not arise as the study of what is common between cultures and nations, but what exists in a given language and in the value system of a given culture. If it is foolish to speak of a universality of linguistic structures (of a kind of semantic and grammatical community between languages), it is nevertheless necessary to go through grammar (i.e., here by studying the meanings of terms in a particular language) to arrive at logic. It would therefore be absurd to speak of universality in the scientific sense for logic without defining it in terms of omni-culturality. We could even use the Wittgensteinian notion of language games to shed light on this complex situation.

The relation of logic to intellect and intelligibles is of the same type as the relation of grammar to language and utterances. All the laws that grammar gives us on the utterances have their analogues in logic for the intelligible ones. (...) As for the objects of logic and on which are the laws, they are the intelligibles as the terms signify them, and the terms in so far as they signify the intelligibles. For we cannot establish the truth of a judgment for ourselves only by reflecting and establishing in ourselves things and intelligibles whose own aim is to establish the truth of this judgment. And we establish the truth for others only by speaking to it with the help of affirmation whose own aim is to establish the truth of this judgment. (...) Logic has in common with grammar the fact of giving the laws of terms, and it differs from it in that grammar gives laws proper to a nation whereas logic gives general common laws for all terms of all nations; for in terms there are modes in which all nations participate, such as their division into singles and compounds, the division of the simple into noun, verb and particle, the fact that some are regular and others irregular, and other similar things. (...) The grammar in each language considers only that which is peculiar to this nation; for what is common to this language and to others, it studies it not as a common but from the point of view of where it is in their particular language. This is the difference between the study of terms by grammarians and logicians: grammar gives laws which concern the terms of a given nation; it considers what is common to this nation and to others from the point of view where it is present in that language of which grammar is made. While logic gives laws of terms only those which are common to the terms of nations; and she considers them from the point of view where they are common. It does not study what is peculiar to the terms of a particular 
nation but recommends to the scholars of that language what might be needed for that particular language [1, pp. 53-62]. ${ }^{12}$

\subsection{Avicenna and the Epistemological Indispensability of Logic}

For Avicenna, logic is both necessary for all forms of knowledge and essential for good thinking.

This is the benefit, he wrote in Kitab Al-Nağat, of the discipline of logic. Its relation to deliberation is [comparable to] the relation of grammar to speech and of prosody to poetry. However, a sound nature and innate faculty of discernment can perhaps dispense with the study of grammar and prosody. [But] there is nothing in human nature that, in using deliberation, can dispense with in preparing this instrument beforehand [7, pp. 4-5].

Avicenna gives a privileged epistemic status to the logic that makes it the instrument of all knowledge. This is what we call the epistemological indispensability of logic or its omni-scientific status, a thesis according to which logic is necessary so that all forms of knowledge can reach a certain degree of certainty and coherence.

This thesis is in opposition to another thesis, namely that of Ibn Taymyyia (d. 1328) that we can call the thesis of the dispensability of logic, in other words the thesis of its vanity and uselessness: what we can do with logic, we can do it without it.

Despite this distinctive status of logic in philosophical practice and in the science system, we can see that it has not been the subject of serious study as such. We have either separated logic (by its formalisms) from philosophy and the whole of knowledge to focus on epistemic processes drawn for most of the physicalistic and naturalistic experience of the world, or cut the logic of any possible anchoring in ethics and politics, and the original contribution it could make to the various issues relating to these areas. Rehabilitating its epistemological character and its anchoring in the anthropological and ethical and political, taking into account both classical Arabic traditions and our current thinking: here is the goal that this article assigns.

In this perspective, we may understand how, from the classical age, logic, in its intimacy with the sciences and philosophy, provided (and did not cease to do so) strong arguments against religious fundamentalist discourse.

\subsection{Averroes on the Unity of Truth}

Averroes takes up the line of thought on the truth already inaugurated by Al-Kindi since the $9^{\text {th }}$ century. For him, it would be foolish to speak of two truths that would contradict one another, a truth based on revelation and another on human reason. From his point of view, one truth cannot be contrary to another truth. But the unity of truth must not exclude what Averroes calls "the hierarchy of human natures in terms of assent" [5, p. 116]. Indeed, the demonstration is not an absolute model of assent for all men, even if this model is unquestionably proven by philosophers and scientists. The Qur'an, because of its universal message to all men, takes this hierarchy into account.

\section{Conclusion}

The study of classical Arab logic from the point of view of its privileged place in the history of natural and formal sciences is not politically innocent. Such an interest is defined above all in terms of a political project that attempts to defeat all forms of withdrawal, extremism, religious fundamentalism, fanaticism, and intolerance. Logic and politics (for Arabs) seem to form an inseparable couple. Such an approach presupposes two ideas beforehand: first, to place logic and the question of its history in the general context of the history of science. Then develop a perspective that focuses on the religious as a discourse. This perspective will take into account the pragmatic turn applied to the case of religious discourse and is apt to unmask the manifest forms of fundamentalism and intolerance in this discourse. Thus, if the difference in beliefs leads to a denial 
of all truths, one of the tasks of philosophy may be to arbitrate beliefs by logic and to monitor religious discourse [15].

Many in both the West and the East hold a skeptical position on the history of Arab sciences and the role they are called to play in epistemological and political cultures. This skepticism emanates above all from Arab and Muslim intellectuals themselves and takes many forms. It can be direct or indirect, conscious or unconscious. There is the case of the specialist who is content to teach Copernicus, Galileo and Descartes as they are the protagonists of a true scientific tradition at the origin of all that is modern in the world. This specialist does not care to link this tradition (embryonic scientist, founder of modern science) to classical Arab traditions and adopts a centralized vision of modernity: Galileo is the father of modern science as Descartes is in terms of thought (the famous cogito ergo sum).

On the other hand, there is the case of the specialist of the Arabic philosophy which draws within this same philosophy two wakes: that Arabic and Greek, and that Islamic, or to take back a famous distinction, a thinker in Islam and a thinker of Islam. This specialist ends up rejecting the first wake in favor of a thought that is inspired more by theology (Kalam), Islamic law and jurisprudence (Fiqh) than logical and mathematical sciences as they have could be developed by the Arabs from the $9^{\text {th }}$ century. I would like to take as a simple example of such a perspective in the Islamic tradition of Arabic language, Taqyi Eddyn Ibn Taymyyia. Ibn Taymyyia has written two great works, Refutation of Logic and Response to Logicians in which he has developed a systematic refutation of the logical procedures in favor of, not the Qur'anic text and the prophetic tradition, but rather of a literal reading of the meaning deployed in these two sacred references.

Ibn Taymyyia ${ }^{13}$ is, no doubt, the founder of a form of intellectual Salafism having as its pivot a sort of approach that we can call theological: to summarize it, we can say that it consists in saying that the truths of revelation have no need to be justified logically by reason and by demonstrative thought processes so that they are accepted as absolute and irrevocable truths. Ibn Taymyia has founded a Theodicea that proves to be the opposite of a Logodicea. ${ }^{14}$

Contrary to what has been done in the field of the history of Arabic sciences, I think that we need to reconsider the place of truth in the logical sense and to promote its role. Indeed, no one can doubt today the important role that logic plays in promoting rational thought that seeks to justify the use of reason to access the truth. If we want today to give a definition of what humanity is, it would probably be the way by which human beings can handle language with predicative, symbolic and relational structure in cultural variations.

I would like to avoid the option which considers that logical reason is not only secondary to absolute truths contained in rigid and static references, but that it is dispensable and often useless, so that it is subject to the principle of conservativeness ${ }^{15}$ of its own truths. I will call this thesis the dispensability or conservativeness of the truths of logic and to which I would oppose diametrically my point of view. But I would not like to hypostatize the truth figures at the very heart of this culture and reduce them to the sole channel of logical truth. This culture remains in many ways traversed by skeptic tendencies as strong as the search for truth itself. ${ }^{16}$

Putting logic at the very heart of classical Arabic sciences, with its conception of truth as an adaptation to a reality while taking into account the structure of the symbolic language in use, will no doubt enable us to explain how classical Arabic logicians have succeeded, thanks to their spirit of creativity and criticism based on doubt and applied intelligence, to embody a model of thought (although it is necessary to situate it in its context) which can inspire, as a horizon of life, the takers of decisions in today's Arab societies.

\section{Acknowledgement}

A French version of this paper was published in François Rivenc's (eds): Figures de vérité, ISTE, London 2019. 


\section{References}

[1] Al-Farabi. Ihsa' al- 'Ulum (The Catalogue of the sciences), Uthman Amin (ed), Cairo: Dar alFikr al-Arabi, 1948.

[2] Alami. A \& G. Badoual, La pensée philosophique dans l'Islam classique, Anthologie thématique, Casablanca: Afrique Orient, 2012.

[3] Al-Kindi. Treatise on First Philosophy, translation with Introduction and Commentary by Alfred L. Ivry, Albany: State University of New York Press, 1974.

[4] Al-Kindi. Epitre sur la philosophie première, In J. Jolivet and R. Rashed (eds.), Euvres philosophiques et scientifiques d'Al-Kindi, Volume II, Métaphysique et cosmologie, Leiden, Boston, Köln: Brill, 1998.

[5] Averroes. Discours décisif, Paris: Garnier-Flammarion, 1996.

[6] Avicenna. Al-Nağat, Commentary by Majed Fakhri, Beyrouth, Dar El Afek El Jedida, 1985.

[7] Avicenna. Avicenna's Delivrance Logic, Translation and Notes by Asad Q. Ahmed, introduction by Tony Street, Oxford: Oxford University Press, 2011.

[8] Benmakhlouf, A. "Le raisonnement et la vérité dans la tradition philosophique médiévale arabe », In La vérité, collection «Les Mots du Monde - Pour un dialogue inter-culturel», Coordination of Nadia Tazi, Translated to arabic by: Abdelkader Qannini, Casablanca, Editions of The Arabic Cultural Center, 2005, pp. 13-44.

[9] Büttgen Ph., De Libera A., Rashed M. \& Rosier-Catash I. Les Grecs, les Arabes et nous, Enquête sur l'islamophobie savante, Paris: Fayard, 2009.

[10] Coran, Essai de traduction de l'arabe annoté et suivi d'une étude exégétique par Jacques Berque, Paris: Albin Michel, 1995.

[11] Fichant, M. Vérité, foi et raison dans la Théodicée, In Lectures et interprétations des Essais de Théodicée de G.W. Leibniz, edited by Paul Rateau, Studia Leibnitiana, Sonderhefte 40, Stuttgart: Franz Steiner Verlag, 2011.

[12] Gouguenheim, S. Aristote au Mont-St-Michel: les racines grecques de l'Europe chrétienne, Paris: Seuil, 2008.

[13] Hallaq, B. W. Ibn Taymyyia against logicians, Oxford: Oxford University Press, 1993.

[14] Hasnawi, A., El-Amrani, J. \& Aouad, M. (eds.). Perspectives arabes et médiévales sur la tradition scientifique et philosophique grecque, preface by Roshdi Rashed, Leuven-Paris: Peeters, 1997.

[15] Heck, P. L. Skepticism in Classical Islam, Moments of Confusion, London: Routledge, 2014.

[16] Jorion, P. Comment la vérité et la réalité furent inventées, Paris: Gallimard, 2009.

[17] Langhlade, J. Du Coran à la philosophie: le langage arabe et la formation du vocabulaire philosophique chez Al-Farabi, prefaced by Jean Jolivet, Damascus: Ifpo Presses, 1994.

[18] Manzur, J. Lisân Al- 'Arab, Jamel Eddin Ibn Manzur, XV Tomes, Beyrouth: Dar Sader, 1992.

[19] Nasr, S. N. The Garden of Truth, The vision and Promise of Sufism, Islam's Mystical Tradition, New York: Harper Collins, 2007.

[20] Priest, G., Beal J. C., \& Armour-Garbi B. The Law of Non-Contradiction, New Philosophical Essays, Oxford: Clarendon Press, 2004.

[21] Taymmyia, I. T. Naqd al-Mantiq, (Réfutation de la logique), M. Ben Abdel Razzaq Hamza (ed.), Cairo: Matba'at al-sunna al-Muhammadyia, 1951.

[22] Taymmyia, I. T. Al-Radd Ala Al-Mantiqyyin (Réponse aux logiciens), A. Samad Sharaf Eddin Al-Kutubi (ed.), Bombey: al-matb’a al Qayyima, 1949.

\section{Notes}

1. [19, p. 30]: “The famous tenth-century Sufi Mansur Al-Hallağ uttered ana al-Haqq, that is, "I am the Truth" or "I am the Real", and paid for it to in Sufi literature alternatively as Allah or al-Haqq, for God is both absolute Truth and absolute Reality with his life, for many misconstrued the real import of these words. These words have nevertheless echoed like an ever-repeated refrain through the annals of Sufism during the past millennium. What is this Truth of which Al-Hallağ spoke, for which he paid with his life, and that all Sufis have sought to attain, considering its 
attainment to be the supreme goal of human life? The term Haqq used by Hallağ is a Qur'anic term. It means both truth and reality and is in fact a Name of God, who is usually referred".

2. See [17] Chapter 3: Les sciences religieuses, p. 111-155.

3. [19] Part II, "The Centrality of Truth".

4. [19, p.30]: "According to Sufism, the supreme goal of human life is to attain Truth, which is also Reality, the source of all reality, and whose attainment, as also stated by Christ, makes us free, delivering us from the bondage of ignorance. Although deeply involved with love and also on a certain level with action, Sufism is at the highest level a path of knowledge ( $m a$ 'rifah in Arabic and 'irfan in Persian), a knowledge that is illuminative and unitive, a knowledge whose highest object is the Truth as such, that is, God, and subsequently the knowledge of things in relation to God. There is such a thing as the Truth, and it can be known. This is the first of all certitudes, from which flow all other certitudes of human life. The knowledge of the Truth is like the light of the sun while love is like the' heat that always accompanies that light".

5. By Omni-cultural universality I want to refer to one of the essential features of the objectivity of science. This is what I refer to as the conjunction, within the same movement, of universality and cultural differences. This trait is indeed the consequence of the historicity of the sciences, including those which are logical, formal and mathematical. Indeed, the universality of all science is not absolute, nor is it the expression of a state of subjective consciousness. It exists and manifests itself in a sense inherent in cultures in their human diversity, closely related to the anthropological context where it is directly involved in the functions of language and practice. If we take the case of logical science for example, we would say that logical concepts are universal and necessary because they possess a structure independent of their cultural determinations, a structure that manifests its effects and imposes its rational and objective properties on all logicians, whether Greek or Arab or European. It is the necessary character of such a structure - that we find almost in all cultures - which establishes the objectivity of logical science and testifies to its autonomy.

6. Graham Priest is among the contemporary logicians who have a direct interest in the philosophical question of contradiction (and of course the logical principle of non-contradiction) to demystify the privileged status it had long occupied (and continues to do today) within our rationality. In several writings, he attempts to present the contradiction in a different light and will not hesitate to defend the thesis of acceptability while showing skepticism vis-à-vis any theory that seeks to establish a necessary relation between our rationality and the law of no contradiction. In a collective work [20], G. Priest gave himself the task of exposing, discussing and dismantling the various objections supposed to nullify the positive contribution of the contradiction. From his point of view, these objections are five in number: (1) The contradictions imply everything. (2) The contradictions cannot be true. (3) The contradictions cannot be the object of a rational belief. (4) If the contradictions were acceptable, people could never criticize them rationally. (5) If the contradictions were acceptable, no one could deny anything.

7. I am referring here to [14], a book compiling the proceedings of the symposium (Paris, 31/03-03/04/1993) of the SIHSPAI (International Society for the History of Science and Islamic and Arab Philosophy) and published with the assistance of the French Ministry of Higher Education and Research and the League of Arab States. It is in this monumental work that I drew the initial intuition underlying all this work.

8. Ali Benmakhlouf's article was translated from French into Arabic by Abdelkader Kennini and published in the collection "Words of the World-For a Dialogue Between Cultures", under the direction of Nadia Tazi and entitled The Truth (Al-Haqiqha). The French version at La Découverte has never been published. The book was actually planned but it never appeared. In any case, I only consulted the Arabic version of this collective volume and from my knowledge the French publisher published only three volumes in 2004, Identity, Male-Female and Experience. On the website of the French publisher, we read the following about this collection: "The collection" The words of the world "is based on a simple idea: to put together in a book a collection of texts that attempt to present the meaning of the same word in different geographical and cultural areas: sub-Saharan Africa, China, United States, Europe, India, Arab world. These philosophical or anthropological terms have acquired a symbolic depth by crystallizing, for a given society, evolutions and striking features. Immersed in the most everyday use, they also found and organize a common language, which also refers to debates in contemporary societies. These books wish to reconnect with a certain intellectual tradition of critical vigilance and openness, while giving themselves the chance of a "distant look" favoring dialogue between cultures. The reader will be able to take the measure of the concordances, the slippages, the disparities covered by each of these 'universal' notions, but also the tensions that are emerging between the diversity of cultural traditions and the work of homogenizing globalization. All titles in the 'Words of the World/Les mots du monde' collection are published in their languages by each of the publishers involved in this collective endeavor: Shanghai Cultural Publisher (China), Arab Cultural Center (Morocco), Other Press (United States), Sage Publications (India), La Découverte (France) ...” As regards the Arabic version of the volume on the truth, the book respects the following geographical order: the truth in the Arab world with the quoted article of Ali Benmakhlouf, the other contributions deal in turn with the truth in Europe, in Africa, in India, in America, and finally in China. The article on the truth in China is titled "On Zhen, On the Truth", and was written by a certain Yung Ju-Rung. There is much to be said about the notion of truth (Zhen) in Chinese culture that leads us to believe that the author's thesis of How truth and reality were invented does not hold.

9. This philosophy began with the translation of Greek science and philosophy by Syriac Christians in the late eighth century.

10. It is not a question of adopting a strong ideological position on this level, a kind of ideological or political commitment that is beyond suspicion by the history of Arab (classical) sciences; it is not a question of (1) separating 
this activity from that of the history of science in general, (2) nor glorifying the past of the Arab-Islamic civilization and its golden age to implement place an anti-Western nationalist ideology politically exploitable. There are indeed several points of view concerning this discipline-activity with regard to its status and its philosophical and theoretical backgrounds, as there are also several forms of ideological recovery or devaluation of the contribution of the Arabic language in classical scientific traditions ([12] is a very representative example. See also the response [9]).

11. See [17, Chapter V: Farabi's Ideas on the Origin and Formation of Language and Languages, p. 191-214, chapter IV: The formation of the language of science, pp. 215-270, and chapter VII: The formation of the philosophical language, pp. 271-307.]

12. [1], Al-Farabi, Ihșa' al- 'Ulum (Sciences Census/Catalogue of the sciences), ed. Uthman Amin, Cairo, Dar al-Fikr alArabi, 1948, pp. 53-62. This passage is also quoted in [2, p. 55-57] and is based on an unpublished translation to French of Jacques Langhade. In any case, Jacques Langhade is a prominent French-speaking specialist in Al-Farabi and he became known through a series of publications on his work including an excellent book [17] prefaced by Jean Jolivet and titled: From the Qur'an to philosophy: the Arabic language and the formation of Farabi's philosophical vocabulary, Damascus, Ifpo Presses, 1994. Other Arabic editions of the book in question exist, and we find at Albouraq a French translation by Amor Cherni published in 2015.

13. [13], HALLAQ B. Wael, Ibn Taymyyia against logicians, Oxford University Press, 1993.

14. The term of de Logodicea is used by Michel Fichant. See [11], Michel Fichant : «Vérité, foi et raison dans la Théodicée» dans : Lectures et interprétations des Essais de Théodicée de G.W. Leibniz, édité par Paul Rateau, Studia Leibnitiana - Sonderhefte 40, Franz Steiner Verlag, Stuttgart, 2011.

15. By this principle I mean that all what we can apply by Logic can be prouvable without it.

16. See the excellent book of Paul L. Heck, Skepticism in Classical Islam, [15]. 